\title{
Prevalence of occult hepatitis B virus infection in kidney transplant recipients
}

\author{
Cibele Franz ${ }^{1 /}{ }^{+}$, Renata de Mello Perez ${ }^{1}$, Mariano Gustavo Zalis ${ }^{2}$, Ana Carolina Jonard Zalona ${ }^{2}$, \\ Pedro Túlio Monteiro de Castro e Abreu Rocha ${ }^{3}$, Renato Torres Gonçalves ${ }^{3}$, \\ Letícia Cancella Nabuco ${ }^{1}$, Cristiane Alves Villela-Nogueira ${ }^{1}$
}

Departamento de Clínica Médica, Serviço de Hepatologia ²Laboratório de Virologia Molecular ${ }^{3}$ Serviço de Nefrologia,
Hospital Universitário Clementino Fraga Filho, Universidade Federal do Rio de Janeiro, Rio de Janeiro, RJ, Brasil

In this cross-sectional study, 207 hepatitis B surface antigen (HBsAg)-negative kidney transplant recipients were evaluated based on demographic and epidemiological data and on the levels of serological markers of hepatitis $B$ virus (HBV) and hepatitis $C$ virus infection and liver enzymes. Patients with HBV or human immunodeficiency virus infection were excluded. Sera were analysed for the presence of $H B V-D N A$. HBV-DNA was detected in two patients $(1 \%)$, indicating occult hepatitis B (OHB) infection (the HBV-DNA loads were 3.1 and $3.5 \mathrm{IU} / \mathrm{mL}$ in these patients). The results of the liver function tests were normal and no serological markers indicative of HBV infection were detected. The prevalence of OHB infection was low among kidney transplant recipients, most likely due to the low HBsAg endemicity in the general population of the study area.

Key words: occult hepatitis B infection - HBV-DNA - kidney transplantation

Occult hepatitis B (OHB) infection is still a topic of debate worldwide. It is defined as the presence of HBVDNA in the liver with HBV-DNA detectable or not in the serum, without detectable HBsAg (Raimondo et al. 2008). Some researchers have noted that OHB could be associated with the risk for the reactivation of HBV infection in patients subjected to long-term immunosuppression (Hoofnagle 2009, Stratta et al. 2009). In addition, OHB may be related to chronic hepatitis of unknown aetiology, cirrhosis and hepatocellular carcinoma (Chemin \& Trepo 2005, Squadrito et al. 2006).

Current evidence indicates that there is a high prevalence of OHB infection among dialysis patients (Altindis et al. 2007, Aghakhani et al. 2010, Motta et al. 2010, Sav et al. 2010); however, the prevalence of OHB infection among kidney transplant recipients remains controversial, with few published data on this subject (Peres et al. 2005, Bae et al. 2012).

End-stage renal disease (ESRD) patients may be at risk for OHB infection due to their use of haemodialysis and history of blood transfusions (Liu et al. 2006, Altindis et al. 2007, Di Stefano et al. 2009).

The aim of this study was to determine the frequency of OHB among kidney transplant recipients and identify the related factors. A cross-sectional study was performed in a low-HBsAg endemicity area from November 2008-May 2010. The study sample included

doi: 10.1590/0074-0276108052013019

+ Corresponding author: franz.cibele@gmail.com

Received 3 October 2012

Accepted 14 February 2013
HBsAg-negative kidney transplant recipients seen at the Renal Transplantation Unit of the Clementino Fraga Filho University Hospital, Rio de Janeiro, Brazil. This study was approved by the Ethical Committee of the Federal University of Rio de Janeiro, Brazil (protocol 118/2008). Patients were recruited during regular appointments and written consent was obtained.

All patients were screened for the following serological markers of $\mathrm{HBV}$ and hepatitis $\mathrm{C}$ virus (HCV): $\mathrm{HB}-$ sAg (Liaison, Diasorin, Italy), hepatitis B core antibody (anti-HBc) and hepatitis B surface antibody (anti-HBs) (Liaison, Diasorin, Italy) and anti-HCV (3rd-generation ELISA, Murex, Abbot, South Africa). The exclusion criteria were human immunodeficiency virus (HIV) infection and chronic HBV infection.

HBV-DNA was extracted from $200 \mu \mathrm{L}$ of plasma using the QIAamp ${ }^{\circledR}$ MinElute Virus Spin Kit (Qiagen). The extracted DNA was stored at $-70^{\circ} \mathrm{C}$ until analysis by real-time polymerase chain reaction (RTPCR). The RT-PCR was performed with the Step One Plus kit (Applied Biosystems) and the sequences of the primers and the probe were as follows: HBVRSV (AGAATCCTCACAATACCGCAGAGT), HBVRSL (CACACGGTAGTTCCC CCTAGAA) and HBVPS (FAMAGACTCGTGGTGGACTTCTCTCAATTAMRA). The primers and probe targeted the $\mathrm{X}$ region of the viral genome. The Taqman ${ }^{\circledR}$ Universal PCR Master Mix (Applied Biosystems) was used for this reaction with the following amplification conditions: 35 cycles of denaturation for $30 \mathrm{~s}$ at $94^{\circ} \mathrm{C}$, annealing for $45 \mathrm{~s}$ at $56^{\circ} \mathrm{C}$ and extension for $1.5 \mathrm{~min}$ at $72^{\circ} \mathrm{C}$. Serum samples that were positive in at least two of the three PCR assays were considered HBV-DNA positive and the patient was diagnosed with OHB infection. The lower limit of detection of the PCR assay was $3 \mathrm{IU} / \mathrm{mL}$. The samples collected for the study were all tested in duplicate. 
A total of 207 HBsAg-negative kidney transplant recipients were included in this study. The demographic, clinical and laboratory data are shown in Table I.

Among the 207 HBsAg-negative patients, two had detectable levels of HBV-DNA, indicating that these patients had OHB infection. Serological markers of HBV infection were not detected in either of these patients. The primary finding of the present study was a very low prevalence of OHB among kidney transplant recipients $(1 \%)$, as previously observed in two similar studies, one by Peres et al. (2005) and the other by Bae et al. (2012); these studies found prevalence of $2 \%$ and $2.7 \%$, respectively. The demographic and laboratory data for the OHB infection patients are shown in Table II.
The prevalence of $\mathrm{OHB}$ infection among renal dialysis patients ranged from $0-50 \%$ in previously published studies (Goral et al. 2006, Altindis et al. 2007, Stratta et al. 2009, Aghakhani et al. 2010, Motta et al. 2010, Sav et al. 2010). The wide range of OHB infection prevalence could be the result of many factors, such as the use of different assays for HBV-DNA detection, viral load (VL) fluctuation in this population and different geographic HBV prevalence among the studied regions.

The 207 kidney transplant recipients included in this study were similar, with respect to the distributions of age, gender and time on dialysis, to the patient populations used in the studies by Peres et al. (2005) and Bae et al. (2012). Peres et al. (2005) used a nested PCR with

TABLE I

Demographic and clinical characteristics of kidney transplant recipients $(n=207)$

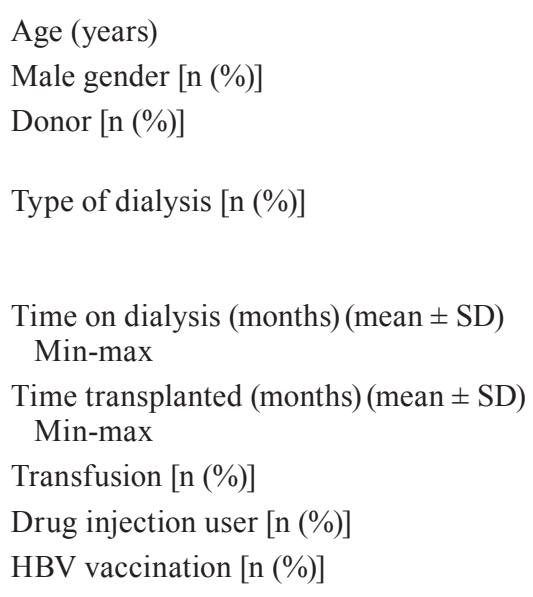

Primary disease $[\mathrm{n}(\%)]$

Type of immunosuppression [n (\%)]

Isolated anti-HBc $[\mathrm{n}(\%)]$

Anti-HBc + anti-HBs [n (\%)]

Anti-HBs [n (\%)]

Anti-HCV [n (\%)]

ALT (IU/mL)

Elevated ALT [n (\%)]

GGT (IU/mL) (median)

Elevated GGT [n (\%)]

HBV-DNA (PCR) [n (\%)]

$$
\begin{gathered}
45 \pm 12 \\
105(51) \\
108(52) \\
99(48) \\
197(95) \\
13(6) \\
4(2) \\
50( \pm 42) \\
0-156 \\
82( \pm 38) \\
13-122 \\
133(64) \\
3(1) \\
130(62) \\
17(9) \\
60(29) \\
64(31) \\
43(21) \\
16(8) \\
55(26) \\
29(14) \\
71(34) \\
42(21) \\
29(14) \\
65(31) \\
2(1) \\
10(5) \\
114(55) \\
25(12) \\
22 \\
46(22) \\
36 \\
67(32) \\
2(1)
\end{gathered}
$$

ALT: alanine aminotransferase; GGT: gama-glutamyl transpeptidase; anti-HBc: hepatitis B core antibodies; anti-HBs: hepatitis B surface antibodies; HBV: hepatitis B virus; HCV: hepatitis C virus; MMF: mycophenolate mofetil; PCR: polymerase chain reaction; SD: standard deviation. 
a limit of detection of 104 copies $/ \mathrm{mL}$, whereas in the present study and the study by Bae et al. (2012), the RTPCR assays had lower limits of detection of $3 \mathrm{IU} / \mathrm{mL}$ (16 copies $/ \mathrm{mL}$ ) and $2 \mathrm{IU} / \mathrm{mL}$ (11 copies $/ \mathrm{mL}$ ), respectively. It is important to use a PCR assay with a low limit of detection because the VL is usually lower than $200 \mathrm{IU} /$ $\mathrm{mL}(1000$ copies $/ \mathrm{ml})$ in OHB patients according to Raimondo et al. (2008).

ESRD patients and kidney transplant recipients have a lower rate of seroconversion after HBV vaccination than the general population. Not only is the seroconversion rate lower, but the anti-HBs levels in those patients who do seroconvert also decline more quickly after immunisation than in healthy individuals (Buti et al. 1992, Choy et al. 2002). These factors could be related to the absence of anti-HBs in most of these patients (such as patient 2) (Table II).

Liver enzyme abnormalities are not common in OHB patients (Aghakhani et al. 2010, Bae et al. 2012); therefore, the normal levels of alanine aminotransferase (ALT) and gamma-glutamil transferase (GGT) found in our study were expected. These normal levels may suggest that OHB infection is a silent infection that does not affect liver biochemistry or liver function. However, these patients should be followed and evaluated on a long-term basis to better understand the outcome and the clinical impact of OHB infection in this specific population.

Although $\mathrm{HBV}$ and $\mathrm{HCV}$ infections share a common epidemiological pattern, an association between $\mathrm{OHB}$ and $\mathrm{HCV}$ has not been clearly established. A higher prevalence of OHB has been found in some studies that evaluated chronic HCV-infected patients (Hui et al. 2006, Shetty et al. 2008, Fang et al. 2009). Although $12 \%$ of patients in the present study were anti-HCV-positive, no HBV-DNA was detected in any of these patients. In the study by Bae et al. (2012), in which there was a $3 \%$ prevalence of HCVinfected patients, no HBV-DNA was detected in any of the HCV-positive patients, as found in our study.

It is possible that the low OHB prevalence observed in this study may reflect the immunosuppressed state of the patients, which could have a permissive effect on HBV replication. However, immunosuppressed patients would be expected to have high HBV VLs and the low VLs associated with OHB infection would be an exception.

In conclusion, the prevalence of OHB infection is low among kidney transplant recipients, possibly due to the low HBsAg endemicity of the general population in the study area. Longitudinal studies focused on the mechanism of OHB infection and its clinical outcomes are required to better understand this entity.

TABLE II

Demographic and laboratory data of the HBV-DNA positive kidney transplant recipients

\begin{tabular}{|c|c|c|}
\hline & \multicolumn{2}{|c|}{ Patients } \\
\hline & 1 & 2 \\
\hline Gender & Male & Female \\
\hline Age (years) & 45 & 39 \\
\hline Type of dialysis & Haemodialysis & Haemodialysis \\
\hline Time on dialysis (months) & 4 & 15 \\
\hline Time after transplant (years) & 9 & 6 \\
\hline Donor & Living & Cadaver \\
\hline Transfusion & None & None \\
\hline Drug injection use & None & None \\
\hline HBV vaccination & Not sure & Yes \\
\hline Immunosuppression & Prednisone/sirolimus/MMF & Prednisone/sirolimus/MMF \\
\hline Primary disease & Hypertensive nephropathy & Diabetic nephropathy \\
\hline \multicolumn{3}{|l|}{ HBV serology pre transplant } \\
\hline Anti-HBs & Negative & Negative \\
\hline Anti-HBc & Negative & Negative \\
\hline \multicolumn{3}{|l|}{ HBV serology pos transplant } \\
\hline Anti-HBs & Negative & Negative \\
\hline Anti-HBc & Negative & Negative \\
\hline Anti-HCV & Negative & Negative \\
\hline ALT & Normal & Normal \\
\hline GGT & Normal & Normal \\
\hline HBV-DNA (UI/mL) & 3.5 & 3.1 \\
\hline
\end{tabular}

ALT: alanine aminotransferase; GGT: gama-glutamyl transpeptidase; anti-HBc: hepatitis B core antibodies; anti-HBs: hepatitis B surface antibodies; HBV: hepatitis B virus; HCV: hepatitis C virus; MMF: mycophenolate mofetil. 


\section{REFERENCES}

Aghakhani A, Banifazl M, Kalantar E, Eslamifar A, Ahmadi F, Razeghi E, Atabak S, Amini M, Khadem-Sadegh A, Ramezani A 2010. Occult hepatitis B virus infection in hemodialysis patients with isolated hepatitis B core antibody: a multicenter study. Ther Apher Dial 14: 349-353.

Altindis M, Uslan I, Cetinkaya Z, Yuksel S, Ciftci IH, Demirturk N, Ozdemir M, Arslan F, Aktepe OC 2007. Investigation of hemodialysis patients in terms of the presence of occult hepatitis B. Mikrobiyol Bul 41: 227-233.

Bae E, Park CH, Ki CS, Kim SJ, Huh W, Oh HY, Kang ES 2012. Prevalence and clinical significance of occult hepatitis B virus infection among renal transplant recipients in Korea. Scand J Infect Dis 44: 788-792.

Buti M, Viladomiu L, Jardi R, Olmos A, Rodriguez JA, Bartolome J, Esteban R, Guardia J 1992. Long-term immunogenicity and efficacy of hepatitis B vaccine in hemodialysis patients. $\mathrm{Am} \mathrm{J}$ Nephrol 12: 144-147.

Chemin I, Trepo C 2005. Clinical impact of occult HBV infections. J Clin Virol 34 (Suppl. 1): S15-S21.

Choy BY, Peiris JSM, Chan TM, Lo SKF, Lui SL, Lai KN 2002. Immunogenicity of intradermal hepatitis B vaccination in renal transplant recipients. Am J Transplant 2: 965-969.

Di Stefano M, Volpe A, Stallone G, Tartaglia L, Prato R, Martinelli D, Pastore G, Gesualdo L, Fiore JR 2009. Occult HBV infection in hemodialysis setting is marked by presence of isolated antibodies to HBcAg and HCV. J Nephrol 22: 381-386.

Fang Y, Shang QL, Liu JY, Li D, Xu WZ, Teng X, Zhao HW, Fu LJ, Zhang FM, Gu HX 2009. Prevalence of occult hepatitis B virus infection among hepatopathy patients and healthy people in China. J Infect 58: 383-388.

Goral V, Ozkul H, Tekes S, Sit D, Kadiroglu AK 2006. Prevalence of occult HBV infection in haemodialysis patients with chronic HCV. World J Gastroenterol 12: 3420-3424.

Hoofnagle JH 2009. Reactivation of hepatitis B. Hepatology 49 (Suppl.): S156-S165.
Hui CK, Lau E, Wu H, Monto A, Kim M, Luk JM, Lau GK, Wright TL 2006. Fibrosis progression in chronic hepatitis $C$ patients with occult hepatitis B co-infection. J Clin Virol 35: 185-192.

Liu CJ, Lo SC, Kao JH, Tseng PT, Lai MY, Ni YH, Yeh SH, Chen PJ, Chen DS 2006. Transmission of occult hepatitis B virus by transfusion to adult and pediatric recipients in Taiwan. J Hepatol 44: 39-46.

Motta JS, Mello FC, Lago BV, Perez RM, Gomes SA, Figueiredo FF 2010. Occult hepatitis B virus infection and lamivudine-resistant mutations in isolates from renal patients undergoing hemodialysis. J Gastroenterol Hepatol 25: 101-106.

Peres AA, Dias EA, Chesky M, Alvares-da-Silva MR, Jobim LF, Gonçalves LF, Manfro RC 2005. Occult hepatitis B in renal transplant patients. Transpl Infect Dis 7: 51-56.

Raimondo G, Allain JP, Brunetto MR, Buendia MA, Chen DS, Colombo M, Craxì A, Donato F, Ferrari C, Gaeta GB, Gerlich WH, Levrero M, Locarnini S, Michalak T, Mondelli MU, Pawlotsky JM, Pollicino T, Prati D, Puoti M, Samuel D, Shouval D, Smedile A, Squadrito G, Trépo C, Villa E, Will H, Zanetti AR, Zoulim F 2008. Statements from the Taormina expert meeting on occult hepatitis B virus infection. J Hepatol 49: 652-657.

Sav T, Gursoy S, Torun E, Sav NM, Unal A, Oymak O, Utas C 2010. Occult HBV infection in continuous ambulatory peritoneal dialysis and hemodialysis patients. Ren Fail 32: 74-77.

Shetty K, Hussain M, Nei L, Reddy KR, Lok AS 2008. Prevalence and significance of occult hepatitis B in a liver transplant population with chronic hepatitis C. Liver Transpl 14: 534-540.

Squadrito G, Pollicino T, Cacciola I, Caccamo G, Villari D, La Masa T, Restuccia T, Cucinotta E, Scisca C, Magazzu D, Raimondo G 2006. Occult hepatitis B virus infection is associated with the development of hepatocellular carcinoma in chronic hepatitis C patients. Cancer 106: 1326-1330.

Stratta P, Bruschetta E, Minisini R, Barbe MC, Cornella C, Tognarelli G, Cena T, Magnani C, Fenoglio R, Toffolo K, Airoldi A, Pirisi M 2009. Prevalence and clinical relevance of occult hepatitis B virus infection in patients on the waiting list for kidney transplantation. Transplant Proc 41: 1132-1137. 